\title{
EVALUATE THERMAL PERFORMANCE OF SOLAR AIR COLLECTORS
}

\author{
Fouda, T. Z.*, M. R., Darwesh**and N. Sh., ELhosary***
}

\begin{abstract}
Solar energy has an important place in sustainable and clean energy sources. Solar collectors can play a vital role among applications of solar energy system. Solar collectors are divided into solar air heating collector (SAHC) and solar water heating collector (SWHC) according to the fluid used. Although its efficiency is low because of air's worse thermodynamic properties in terms of heat exchange compared to liquid, SAHC is still widely used in the world for the advantages of simple structure, convenient installation and easy maintenance. The absorber surface material is the most important parameter in the design for solar air collectors. The present study aimed to evaluate the thermal performance of solar air collectors. The treatments under this study were three types of solar panels absorbent. Stainless steel, aluminum and iron) and three different air velocities of 1.7, 2.4 and $3.6 \mathrm{~m} / \mathrm{s}$ represented. Stainless steel solar panels absorbent give the highest value of absorption efficiency, useful heat gain to storage and overall thermal efficiency and they were 86.4, 71.42 and $59.87 \%$, respectively at midday air flow inlet temperature $\left(\right.$ Tai $\left.=31.7 \mathrm{C}^{\circ}\right)$, air flow outlet temperature $\left(\right.$ Tao $\left.=49.9 \mathrm{C}^{\circ}\right)$ and Average plate temperature $\left(\mathrm{Tpm}=70 \mathrm{C}^{\circ}\right)$ at $2.4 \mathrm{~m} / \mathrm{s}$ fan velocity.
\end{abstract}

\section{INTRODUCTION}

\begin{abstract}
$\mathrm{S}$ olar air heaters are employed in many applications requiring low to moderate temperatures (below $60^{\circ} \mathrm{c}$ ), such as crop drying and space heating. These solar collectors are very simple and cheap; therefore they are widely used as devices which can collect solar energy. The important key parameter is the thermal performance of these solar air heaters. Many researchers indicated that the efficiency of these heaters are very poor because of their inherently low heat transfer capability between the absorber plate and the air flowing through collector.
\end{abstract}

\footnotetext{
*Prof. of Agri. Eng. Dept., Fac. of Ag., Tanta. Univ. **Associate Professor. in Agric. Eng, Dept., Fac. of Ag., Tanta univ. ***Demonstrator in Agric. Eng, Dept., Fac. of Ag., Tantauniv.
} 
Hassanain (2009) constructed a solar dryer composed of a solar collector, a drying chamber and a solar chimney and/or blower. The air type solar collector was fixed altitude angleat $30^{\circ}$. The drying chamber was flexible to be $0^{\circ}$ and $90^{\circ}$ with the horizon axis. Simple passive and active designs were followed to enable save energy requirement for fan operating. Emaraet al. (2010) found that at the minimum air velocity of $0.4 \mathrm{~m} / \mathrm{s}$, the solar collector of the dryer could increase the average air temperature inside the dryers having sugar beet tops of 3, 6 and $9 \mathrm{~cm}$ lengths by about $11.05,11.63$ and $11.25{ }^{\circ} \mathrm{C}$ and decreased the air relative humidity by about 24.84, 26.09 and $24.98 \%$, respectively. While at the maximum air velocity of $1.2 \mathrm{~m} / \mathrm{s}$, air temperature increased by about 10.79, 11.99 and $11.94{ }^{\circ} \mathrm{C}$ and air relative humidity decreased by about $24.17,26.47$ and $26.81 \%$, respectively. Basumatary et al. (2013) designed and constructed a low cost mixed type solar cabinet dryer. Saxena and Goel (2013) pointed out that flat plate designs mainly consist of three major parts. These are transparent cover, absorber plate and insulation. The transparent cover also called glazing is where the solar energy passes through the collector. Bayrak and Oztop (2015) investigated the energy analysis of flat-plate solar air collectors (SACs) with porous obstacles at two different thicknesses and without obstacles (flat plate). As a porous material aluminum foams are used. They are placed sequentially and in a staggered manner onto the cover of the SACs. The measurements are performed at two different values of air mass flow rate as $0.016 \mathrm{~kg} / \mathrm{s}$ and $0.025 \mathrm{~kg} / \mathrm{s}$ and with thickness of $6 \mathrm{~mm}$ and $10 \mathrm{~mm}$. The obtained results showed that the highest collector efficiency and air temperature rise were achieved by SACs at $6 \mathrm{~mm}$ thickness and $0.025 \mathrm{~kg} / \mathrm{s}$ air mass flow rate. Salehand Rashid (2016) Manufactured air solar collector with a dimensions of $120 \mathrm{~cm} \times 90 \mathrm{~cm} \times 12 \mathrm{~cm}$ length, width and thickness, was tested underclimate conditions of Baghdad city with a (43 tilt angel). Theoretically, the results showed that the collector with high convention heat transfer coefficient porous media has high hourly efficiency about $(\eta=56 \%)$ and iron wire mesh on absorber $(\eta=52 \%)$, on the other side the minimum performance occurred in the flat plate absorber $(\eta=$ $28 \%$ ).Shuilian etal. (2017) using four types of air solar collectors: sinusoidal corrugated plate, protrusion plate, sinusoidal corrugated and 
protrusionplate and a base flat-plate collector are presented. The results of the experiments were evaluated at thesame time of the days with the same radiation. The efficiencies were determined for the collectors andcomparisons were made among them. The present data showed that heat transfer coefficient and pressure drop and the performance factor (PF) increase with shape of absorbers surface. Jie Deng et al. (2017)stated that the unified airside convective heat transfer coefficient for different sorts of flat plate solar air collectors (FPSACs) is identified in terms of collector aperture area It is found that the airside convective heat transfer coefficient can be experimentally determined by collector thermal performance test method to compare the airside thermal performances of (FPSACs) with different types of airflow structures. The results indicate that the effective way of decreasing total entransy dissipation and enhancing the useful entrance increment is improving the efficiency intercept of the (FPSAC). Forson et al. (2017) designed three main components of the dryer as an air-heater(primary collector), a drying chamber and a chimney. The top cover and sidewalls of the drying chamber are made to be transparent so that they could serve as a secondary collector. The dryer was used to dry Cassava and the drying efficiency was estimated to be $12.3 \%$ with a drying time of 35.3 hours. The dryer was loaded with $162 \mathrm{k.g} ., 28.2^{\circ} \mathrm{C}$ mean ambient temperature and initial moisture content of $66 \%$, the final moisture content of the dried product was measured to be $17.3 \%$ while the temperature of the heated air in the air heater rose by about $10.9^{\circ} \mathrm{C}$. From the previous presentation showed that the thermal efficiency of a solar air heater is a function of many design and operating parameters. Therefore, the aim of this study are evaluate the thermal performance of air solar collector using different absorber plates made from various materials. Also, test this performance with different fan change velocities.

\section{MATERIALS AND METHODS}

The experimental work was executed on the roof of the Faculty of Agriculture, Tanta University, Sebrby, Gharbyia Governorate, which located at latitude and longitude angle of $30.49^{\circ} \mathrm{N}$ and $30.59^{\circ} \mathrm{E}$, respectively. This trails concluded during April month 2017. 


\section{The solar collectors:}

They have different corrugated black painted absorber plate materials (iron, stainless steel and Aluminum).The thickness of all absorber plate was $0.5 \mathrm{~mm}$. The top surface of the solar collector was covered by a glass sheet of $5 \mathrm{~mm}$ thickness. The front side was made from a perforated stainless steel sheet as a window for air inlet. The window dimensions are $920 \mathrm{~mm} \times 150 \mathrm{~mm}$ as shown in Fig (1) .

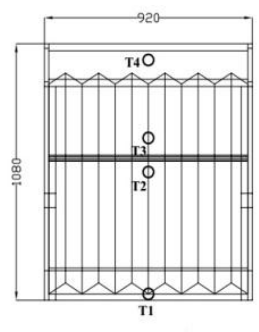

Elevation

All dimensions in $\mathrm{mm}$

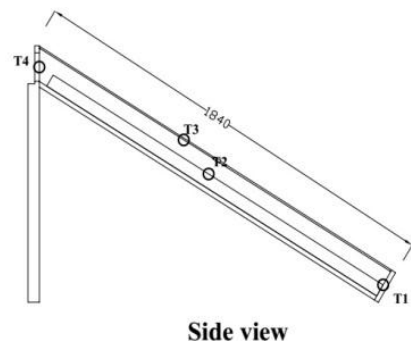

Side view

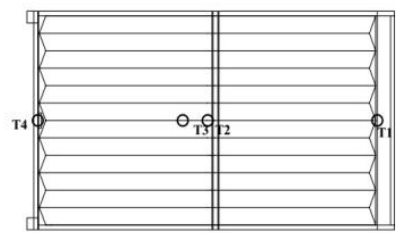

Plan

Fig (1): The air solar collector system.

\section{Instrumentation}

\section{a-The global positioning system (Gps)}

A GPS model etrex30 was used to determine the coordinates of experiments location. GPS etrex 30 have 1.7 GB built-in memory to store user data and to receive additional, more detailed maps which can be transferred from a PC to the GPS. The etrex 20x and 30x have 3.6 GB built-in memory to store user data and to receive additional, more detailed maps, however, 3.3 GB are occupied by the pre-installed map. Theetrex $30 / 30 \mathrm{x}$ are equipped with an electronic 3D compass to check the heading while not moving ${ }^{1}$, accuracy $\pm 5^{\circ}$, resolution $\pm 1^{\circ}$, can be turned off to safe power. "3D" means tilt-compensated compass which does not require the device to be level for accurate readings. Integrated antenna to receive signals of GPS and GLONASS satellites. Supports more than 100 different data (coordinate systems) the global positioning system (GPS). 


\section{b-Data logger}

A twelve Mt-512 temperature controllers and indicator with a control temperature ranged from-50 to $75 \mathrm{C}$ were used for and recording temperature with joined cyclical timer at different positions at three solar collectors. It also had a serial output for communication with the SITRAD. SITRAD is Full Gauge Controls' software for LOCAL module: must be installed on the computer to which the controllers are connected through a serial converter (CONV32). In other words, it must be installed close to the controllers, The sheet reader appear the number of sensor and the temperature value which meet it. The time interval for data recording was 5 minutes with data acquisition every one minute for integrated measurements. The calibrations of all sensors were completed successfully at the beginning of the experimental work.

\section{c-Anemometer}

An anemometer (model TFA) was used to measure air flow speed from furnace outlet. The anemometer had a range of 0.2 to $30 \mathrm{~m} / \mathrm{s}$ with an accuracy of $\pm 5 \%$ least significant digit .

\section{d-Solar power meter}

A solar powermeter was used to measure the solar radiation in the place of the experiment, The specifications of summarized in the following.

\section{Range Resolution Accuracy $1999 \mathrm{~W} / \mathrm{m}^{2}$ $1 \mathrm{~W} / \mathrm{m}^{2}$ $< \pm 3 /$ year \\ e-Air suction unit:}

An axial flow fan with five blades was fixed at the top of the drying chamber for air suction through the drying bed. Specifications of motor are 220-230 V, 50-60 $\mathrm{Hz}, 16 \mathrm{~W}, 0.5 \mathrm{~A}$ and 1300-1550 rpm.

\section{Measurements}

\section{Temperature}

Four sensors were used to measure the temperature for each type of solar collector. The temperature of(air inside the solar collector, outside air, absorber plate and the glass).

\section{Methods:}

Experiments were carried out using Three types of solar air absorbent(Stainless steel, aluminum and iron) and three different air velocities of 1.7, 2.4 and 3.6 $\mathrm{m} / \mathrm{s}$ represented to evaluate their thermal performance test under same climatic 
conditions. The solar air collectors were orientated facing south and tilted to an angle of $30^{\circ}$ to maximize the solar radiation incident on the glass cover.

\section{Calculations}

\section{Air mass flow rate:}

$$
\mathrm{m}_{\mathrm{a}}=\rho_{\mathrm{a}} \cdot \mathrm{V}_{\mathrm{a}} \cdot \mathrm{A}_{\text {duct }}
$$

Where $m_{a}$ is the air mass flow rate $(\mathrm{kg} / \mathrm{s}), \rho_{\mathrm{a}}$ is the air density $\left(\mathrm{kg} / \mathrm{m}^{3}\right), \mathrm{V}_{\mathrm{a}}$ is the average air velocity $(\mathrm{m} / \mathrm{s})$ and $A_{\text {duct }}$ is the apparent solar radiation at air mass $=0\left(\mathrm{~m}^{2}\right)$

\section{Thermal performance of the solar collector:}

Available Solar Energy (Q):

$$
\mathrm{Q}=\mathrm{R} \text {. Ac }
$$

Where $\mathrm{Q}$ is the available Solar Energy(watt), $\mathrm{R}$ is the solar energy flux incident on the surface of solar collector $\left(\mathrm{W} / \mathrm{m}^{2}\right), \mathrm{Ac}$ is the surface area of the solar collector $\left(\mathrm{m}^{2}\right)$.

\section{2-Absorbed Solar Energy (Qa):}

$$
\mathrm{Qa}=\tau . \alpha \cdot \mathrm{R} . \mathrm{Ac}
$$

Where $\mathrm{Q}_{\mathrm{a}}$ is the absorbed solar energy (Watt), $\tau$ is the effective transmittance of solar collector cover system, $\tau=\tau_{\max }-0.00437 \exp [0.0936(\theta-30)]$, (decimal), $\alpha$ is the effective absorbance of the absorber plate of collector, $\alpha=\alpha \max -$ $0.00476 \exp [0.0940(\theta-35)],(\mathrm{decimal}), \theta=$ Solar incident angle.

\section{3 - Absorbtion efficiency:}

$$
\eta_{a}=\frac{Q_{a}}{Q}
$$

Where $\eta \mathrm{a}$ is theabsorption efficiency (\%)

\section{4 - Useful heat gain to storage (Oc):}

$$
\mathrm{Qc}=\mathrm{m}^{\circ} . \mathrm{Cp} \text {. (Tao-Tai), Watt }
$$

Where $\mathrm{m}^{\circ}$ is the mass flow rate of air( $\left.\mathrm{kg} / \mathrm{s}\right), \mathrm{Cp}$ is the specific heat of $\operatorname{air}\left(\mathrm{J} / \mathrm{kg} /{ }^{\circ} \mathrm{C}\right)$, Tao is theoutlet temperature of air $\left({ }^{\circ} \mathrm{C}\right)$ and Tai is the inlet temperature of air $\left({ }^{\circ} \mathrm{C}\right)$.

\section{5- Heat transfer efficiency:}

$$
\eta_{h}=\frac{Q_{c}}{Q_{a}} \times 100
$$

Where $\eta_{\mathrm{h}}$ is the heat transfer efficiency $(\%)$.

\section{6- Solar collector heat losses (QL):}

$$
\mathrm{QL}=\mathrm{Qa}-\mathrm{Qc}
$$


Where QL is the solar collector heat losses (Watt).

\section{7- Overall thermal efficiency:}

$$
\eta_{s}=\frac{Q_{c}}{Q} \times 100
$$

Where $\eta_{\text {sis }}$ the overall thermal efficiency $(\%)$.

\section{RESULTS AND DISCUSSION}

\section{Hourly average solar radiation}

The solar radiation flux incident on the tilted surface of the solar collector is an important factor used to analyze the thermal performance of the air solar collectors. Tabel 1 shows the relationship between the hourly average solar radiation values during day time. This Table indicates the maximum solar radiation value at noon time because the incident angle has a lower value in this time.

\section{Table 1: The hourly average solar radiation during April 2017.}

\begin{tabular}{|c|c|}
\hline Time & Solar radiation, $\mathrm{W} / \mathrm{m}^{2}$ \\
\hline $09: 00$ & 380 \\
\hline $10: 00$ & 500 \\
\hline $11: 00$ & 980 \\
\hline $12: 00$ & 1200 \\
\hline $13: 00$ & 1200 \\
\hline $14: 00$ & 1000 \\
\hline $15: 00$ & 805 \\
\hline $16: 00$ & 610 \\
\hline $17: 00$ & 210 \\
\hline
\end{tabular}

The relationship of (Tai ,Tao,Tpm) inlet air ,outlet air and absorber plate temperatures,respectively, with time at air velocities $1.7,2.4$ and $3.6 \mathrm{~m} / \mathrm{sis}$ shown in Fig. 2, , It can be seen that the maximum value reached at noon (Tai $=30.1$ $\mathrm{C}^{\circ}$, Tao $=48.5 \mathrm{C}^{\circ}$, Tpm $=63.2 \mathrm{C}^{\circ}$ ), Fig. 3 , shows thatat air velocity $2.4 \mathrm{~m} / \mathrm{s}$ the maximum value reached at midday $\left(\right.$ Tai $=31.7 \mathrm{C}^{\circ}$, Tao $=49.9 \mathrm{C}^{\circ}, \mathrm{Tpm}=70 \mathrm{C}^{\circ}$ ) and at air velocity $3.6 \mathrm{~m} / \mathrm{s}$ the maximum value reached at midday (Tai $=29.4$ $\mathrm{C}^{\circ}$, Tao $=46.6 \mathrm{C}^{\circ}, \mathrm{Tpm}=68.1 \mathrm{C}^{\circ}$ ) as shown in Fig. 4 that because being the incident radiation maximum at the same time. 


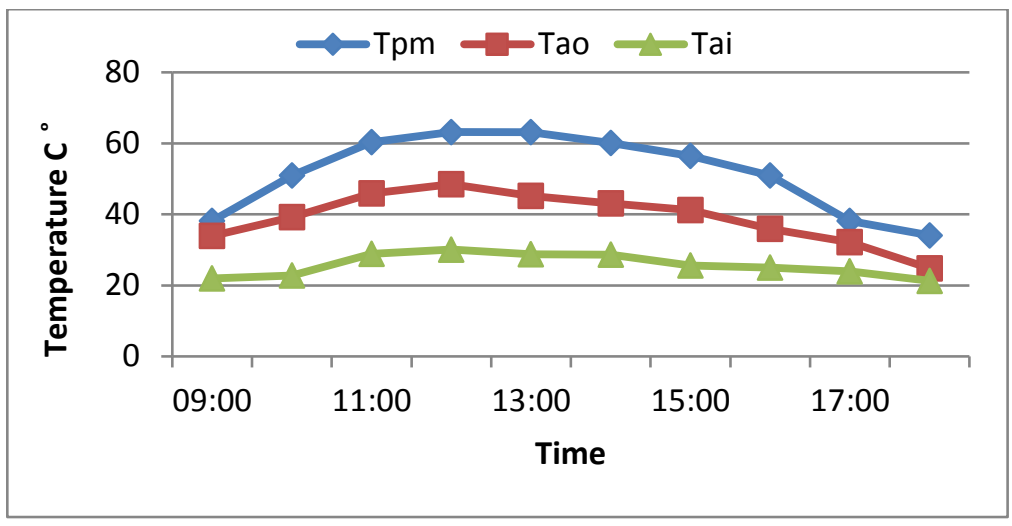

Fig. 2. The inlet air, outlet air and platetemperatures with time of day at $1.7 \mathrm{~m} / \mathrm{s}$ air velocity with stainless steel absorber plate.

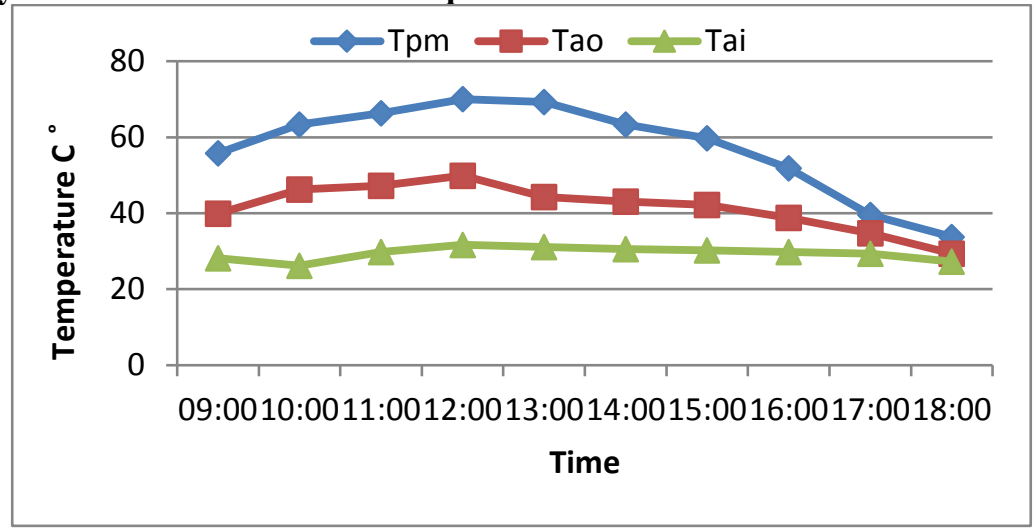

Fig. 3. The inlet air, outlet air and platetemperatures with time of day at $2.4 \mathrm{~m} / \mathrm{s} \mathrm{air}$ velocity with stainless steel absorber plate.

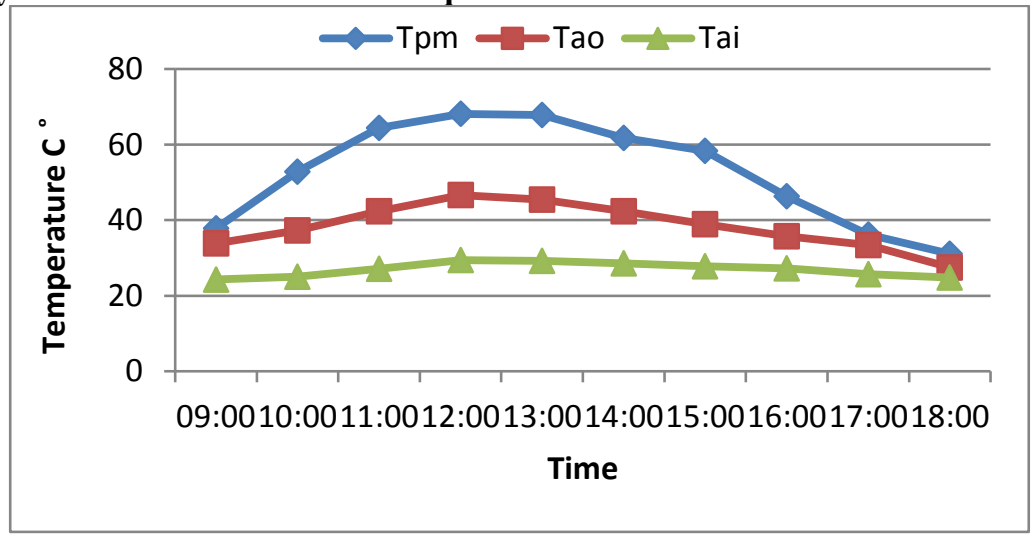

Fig. 4. The inlet air, outlet air and plate temperatures with time of day at3.6 m/s air velocity and stainless steel absorber plate. 
Aluminum Absorber Plate: The relation ship of (Tai ,Tao,Tpm ) inlet air ,outlet air and plate temperatures respectively with time at air velocities $1.7 \mathrm{~m} / \mathrm{s}$ as shown in Fig. 5. It can be seen that the maximum value reached at midday $\left(\right.$ Tai $=30.1 \mathrm{C}^{\circ}$,Tao $=47.3 .8 \mathrm{C}^{\circ}$, Tpm $=63.9 \mathrm{C}^{\circ}$ ), Fig. 6 , shows that at air velocities $2.4 \mathrm{~m} / \mathrm{s}$ the maximum value reached at midday (Tai $=31.7 \mathrm{C}^{\circ}$, Tao $=48.8 \mathrm{C}^{\circ}, \mathrm{Tpm}=60.8 \mathrm{C}^{\circ}$ ) and at air velocities $3.6 \mathrm{~m} / \mathrm{s}$ the maximum value reached at midday $\left(\mathrm{Tai}=29.4 \mathrm{C}^{\circ}\right.$, Tao $=45.9 \mathrm{C}^{\circ}, \mathrm{Tpm}$ $=63.6 \mathrm{C}^{\circ}$ ) as shown in Fig. 7 that because being the incident radiation maximum at the same time.

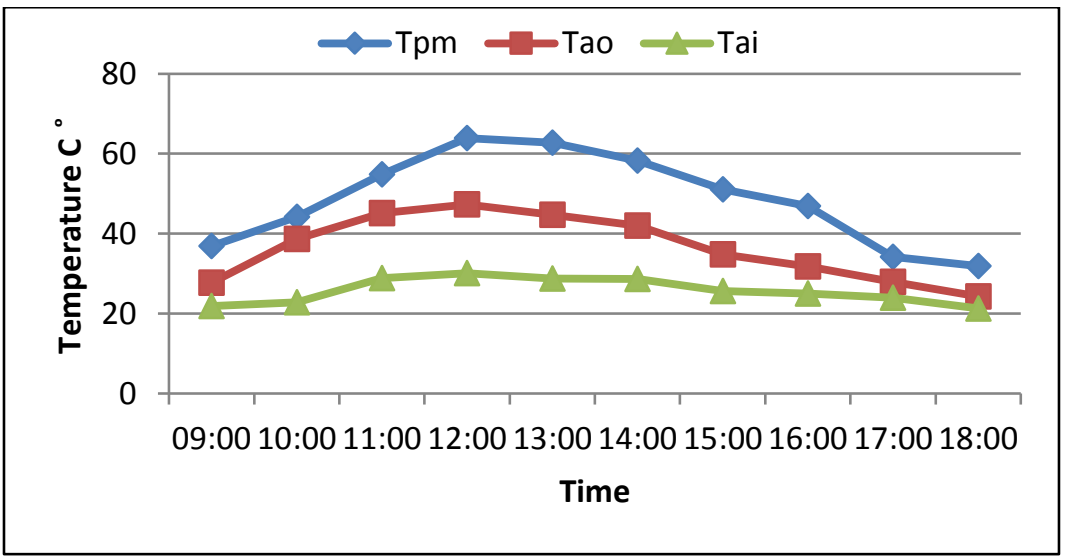

Fig. 5. The inlet air, outlet air and plate temperatures with time of day at $1.7 \mathrm{~m} / \mathrm{s}$ air velocity with aluminum absorber plate.

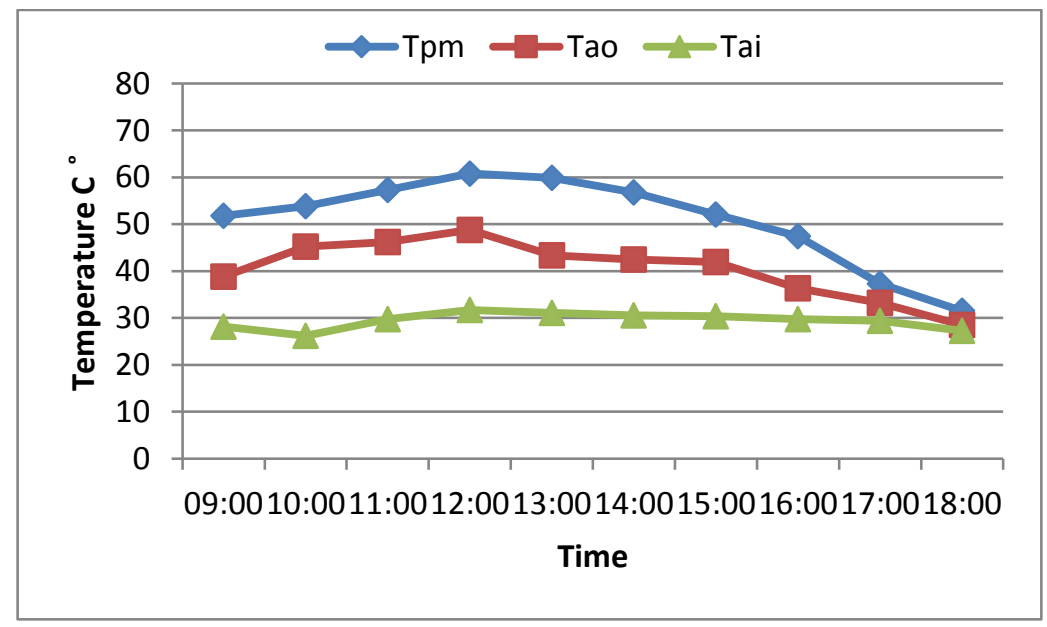

Fig. 6. The inlet air, outlet air and plate temperatures with time of day at2.4 $\mathrm{m} / \mathrm{s}$ air velocity with aluminum absorber plate. 


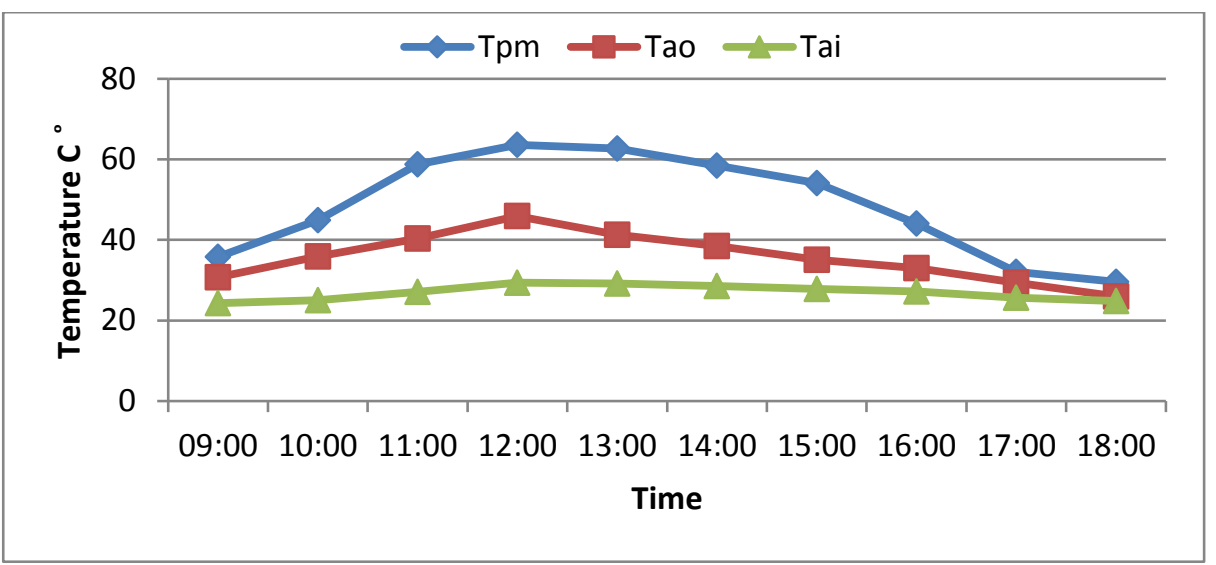

Fig. 7. The inlet air, outlet air and plate temperatures with time of day at3.6 $\mathrm{m} / \mathrm{s}$ air velocity and aluminum absorber plate.

Iron Absorber Plate: The relationship of (Tai,Tao,Tpm) inlet air ,outlet air and plate temperatures respectively with time at $1.7 \mathrm{~m} / \mathrm{s}$ air velocity as shown in Fig. 8 It can be seen that the maximum value reached at midday $\left(\right.$ Tai $=30.1 \mathrm{C}^{\circ}$, Tao $=45.6 \mathrm{C}^{\circ}, \mathrm{Tpm}=53.1 \mathrm{C}^{\circ}$ ), Fig. 9 , shows that at $2.4 \mathrm{~m} / \mathrm{s}$ air velocity the maximum value reached at midday (Tai $=31.7 \mathrm{C}^{\circ}$, Tao $=44.4 \mathrm{C}^{\circ}, \mathrm{Tpm}=56.2 \mathrm{C}^{\circ}$ ) and at $3.6 \mathrm{~m} / \mathrm{s}$ air velocity the maximum value reached at midday (Tai $=29.8 \mathrm{C}^{\circ}$, Tao $=41.2 \mathrm{C}^{\circ}$, Tpm $=52.9 \mathrm{C}^{\circ}$ ) as shown in Fig. 10 that because being the incident radiation maximum at the same time.

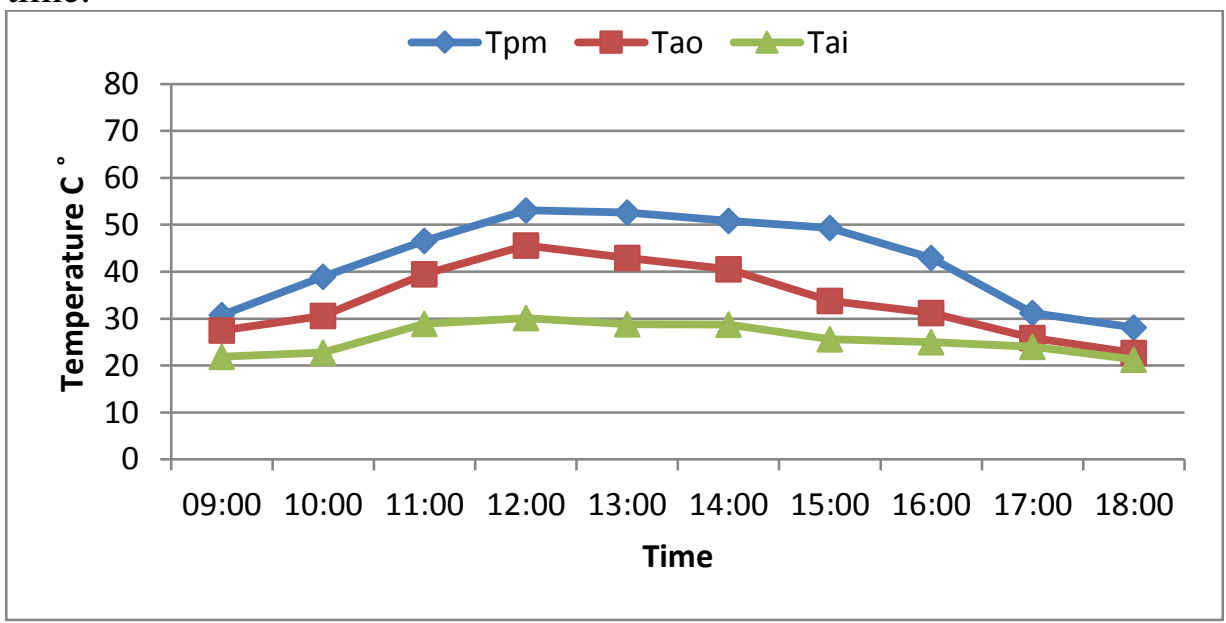

Fig. 8. The inlet air, outlet air and platetemperatures with time of day at $1.7 \mathrm{~m} / \mathrm{s}$ air velocity with ironabsorber plate. 


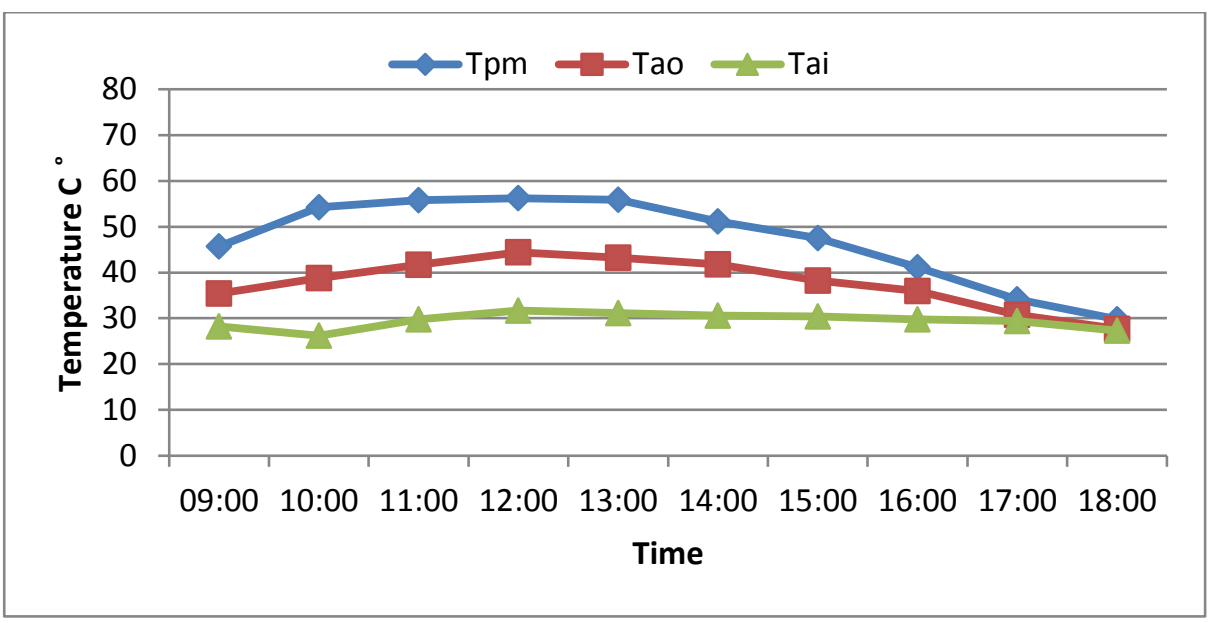

Fig. 9. The inlet air, outlet air and platetemperatures with time of day at $2.4 \mathrm{~m} / \mathrm{sair}$ velocities with ironabsorber plate.

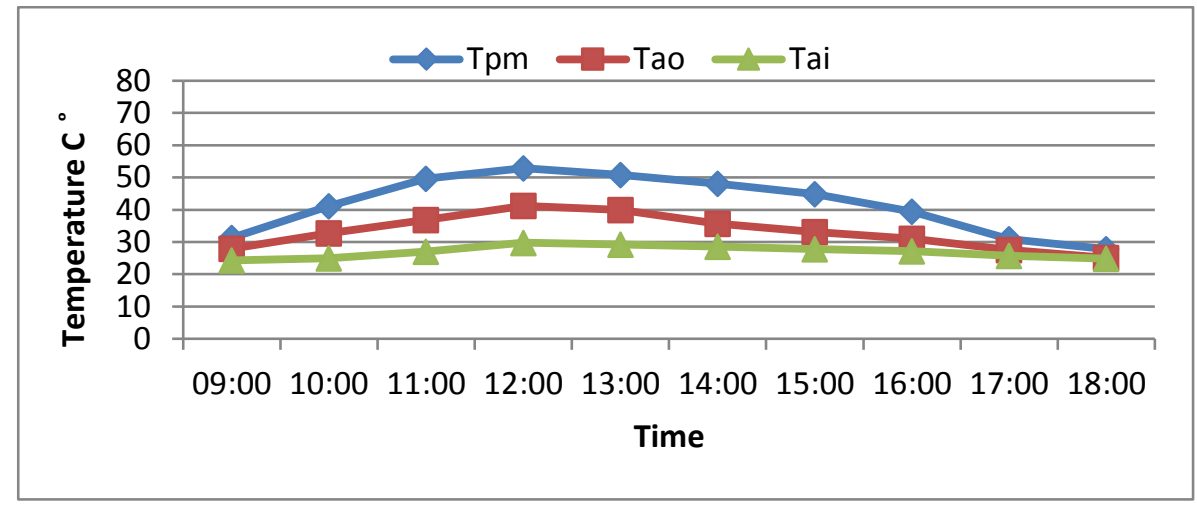

Fig.10. The inlet air, outlet air and platetemperatures with time of day at $3.6 \mathrm{~m} / \mathrm{sair}$ velocity andironabsorber plate.

\section{The Useful Energy of Three Types of Absorber Plate}

The performance curve study for three types of air solar collectors(stainless steel, aluminum and iron) wastested in this studyat three air velocities 1.7, 2.4 and $3.6 \mathrm{~m} / \mathrm{s}$ on the average of useful energy. Stainless steel absorber plate produced the highest value in comparison to aluminum and iron as shown in Fig.11. Also, air velocity gives maximum value at velocity $2.4 \mathrm{~m} / \mathrm{s}$. The results as well as demonstrated that $2.4 \mathrm{~m} / \mathrm{s}$ air velocity produced higher values which composed with other velocity rates. 


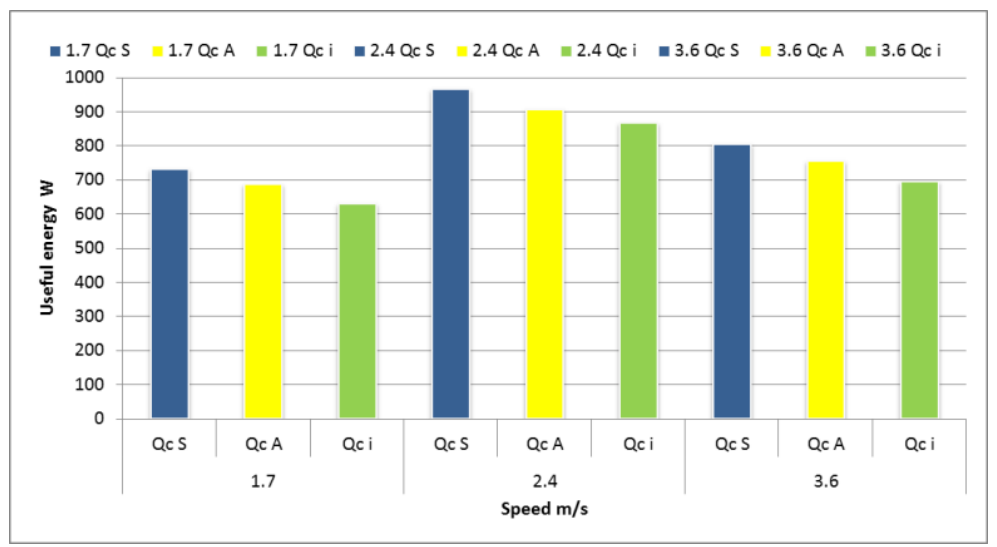

Fig. 12. Useful energy (Qc) and air velocities $(1.7,2.4$ and $3.6 \mathrm{~m} / \mathrm{s})$ at three absorber plates stainless steel (S), aluminum (A) and iron (I).

\section{The Efficiency Curve of Three Types of Absorber Plates}

The performance table of experimentalstudy for three types of air solar collectorstested in this study which isstainless steel, aluminum and iron typesand their values given in Table 1.Air velocity $2.4 \mathrm{~m} / \mathrm{s}$ is the best velocity.

\section{Table 1,average Efficiency of threeair solar collector types}

\begin{tabular}{|lll|}
\hline Absorber type & Air velocities $\mathrm{m} / \mathrm{s}$ & Average Efficiency \% \\
Stainless steel & 1.7 & 57.71 \\
\cline { 2 - 3 } & 2.4 & 59.87 \\
\hline \multirow{3}{*}{ Aluminum } & 3.6 & 55.63 \\
\hline \multirow{3}{*}{ Iron } & 1.7 & 53.97 \\
\hline & 2.4 & 55.27 \\
\hline & 3.6 & 53.47 \\
\hline & 2.7 & 50.12 \\
\hline
\end{tabular}

\section{CONCLUSIONS}

The conclusions drawn from the experimental and analytical studies can be summarized as the following:

_ The hourly solar radiation, useful energy exhibit parallel changes with the incident radiation .i.e. they depend directly on the amount of the solar radiation for any air flow rate. 
_ The efficiency of the collector improves with increasing mass flow rate forever type of absorbers due to an enhanced heat transfer to air flow.

_ The thermal performance of solar air heater with solar panels absorbent material stainless steel gave higher values than, aluminum and iron respectively. Hence stainless solar panels absorbent are recommended.

_ Solar air collector with (stainless steel)material in the air pass gives maximum thermal efficiency among the solar collector types.

\section{REFERENCES}

Basumatary, B.,Roy.,M.Basumatary, S. Nazary., U. Deuri., Nayak and N. Kumar.(2013). Design, construction and calibration of low cost solar cabinet dryer.International Journal of Environmental Engineering and Management,4(4): 351-358

Bayrak F. and Hakan F. Oztop (2015). Experimental analysis of thermal performance of solar air collectors with aluminum foam obstacles. Is1 BilimiveTekniğiDergisi, 35, 1, 11-20, 2015 J. of Thermal Science and Technology TIBTD Printed in Turkey ISSN $1300-3615$

Emara,R.Z. ;M.M,Abo-Habaga and M.M,El-Kholy (2010). A study on handling some fooder crops.M.Sc.in Agricultural sciences (Agric.Eng.)Mansoura University, Egypt.

Forson, F. K., M. A. A. Nazha, F. O. Akuffo and h. Rajakaruna. (2017). Design of mixed -mode natural convection solar crop dryers: Application of principles and rules of thumb. Journal of Renewable Energy, 32(14):23062319

Hassanain, A. A. (2009). Simple Solar Drying System for Banana Fruit. World Journal of Agricultural Sciences 5 (4): 446-455, 2009. ISSN 1817-3047. (C) IDOSI Publications, 2009.

Jie Deng, Xudong Yang, YupengXu, Ming Yang (2017). Entransy analysis on the thermal performance of flat plate solar air collectors.BUILD SIMUL 10: 193-202

Saleh, A. A., T. A. Rashid (2016). Experimental and theoretical study for performance enhancement of air solarcollectors by using different absorbers. Al-Khwarizmi Engineering Journal, Vol. 12(3): $110-120$ 
Saxena,A. and V. Joel (2013). Solar air heaters with thermal heat storages ,chinese journal of engineering, volume 2013, articles ID 190279

\section{Shuilian Li, Hui Wang, Xiangrui Meng and Xinli Wei (2017).}

Comparative study on the performance of a new solar air collector with different surface shapes. Applied thermal engineering 114 (2017) 639-644

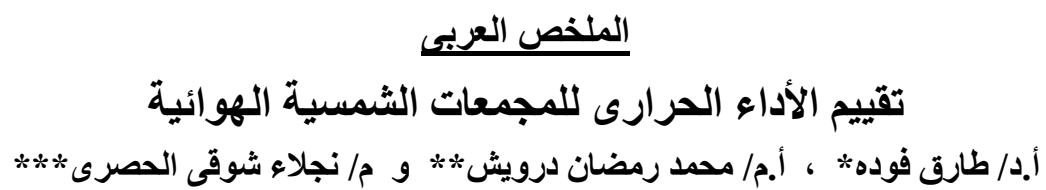

أجريت هذه الدر اسة فى كلية الزر اعة جامعة طنطا بمجمع الكليات بمحافظة الغربية و التى تقع

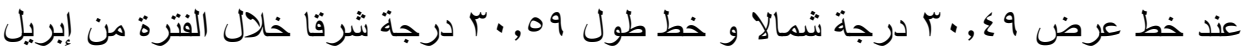

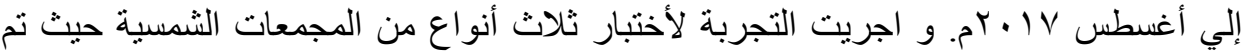
توجيه المجمعات ناحية الجنوب الغربي. و تم تقييم الاداء الحرارى للمجمعات الشمسية الهو ائية. بأستخدام أسطح امتصاص مختلفة (الاستانلس استيل و الألو منيوم و الحديد). و كاتت العوامل تحت الدراسة هى : ـ ثلاث مجمعات اسطح امتصاص مختلفه (الاستانلس استيل

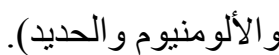

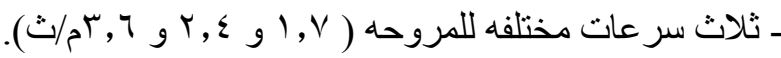
و كاتت القياسات : شدة الاشعاع الثمسىـ درجة حرارة الهو اء المحيط ـ درجة حرارة ارة دخول و و خروج الهواء. و كذاللك تم حساب: الطاقة الثمسية المتاحة ـالطاقة الثمسية الممتصة ـالحرارة المكتسبة و المستفاد منها فى التخزين ـ الحرارة المفقوده من المجمع الثمسي ـ كفاءة الامتصـاص ـ كفاءة عملية انتقال الحرارة- الكفاءة الحر ارية الكلية.

النتائج: ولقد أعطى المجمع الثمسى ذات سطح الامتصاص من الاستانلس استنيل افضل كفاءة

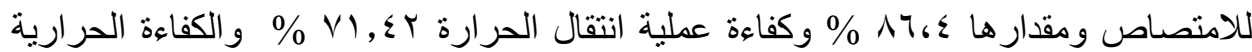

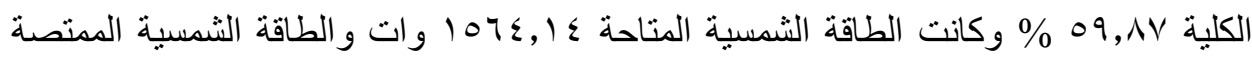

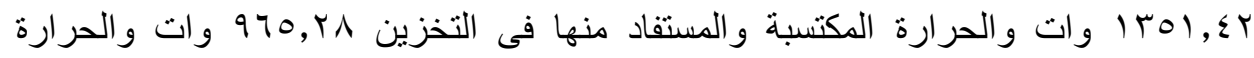

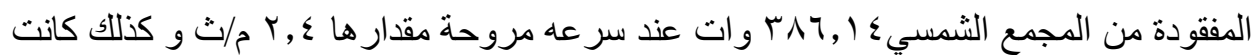

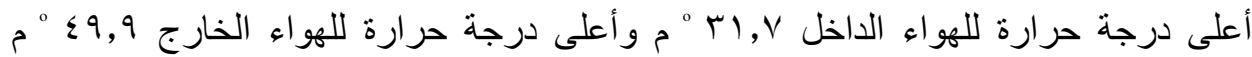
و منوسط درجة حرارة المجمع الثمسى • V درجة مئوية.

*أستاذ الهندسة الزراعية ـ قسم الهندسة الزراعية ـ كلية الزراعة ـ جامعة طنطا.

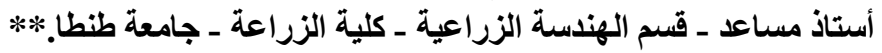

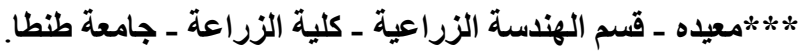

